\title{
Differential gene expression after total replacement of dietary fish meal and fish oil by plant products in rainbow trout (Oncorhynchus mykiss) liver
}

\author{
S. Panserat ${ }^{a, b, c, ~}{ }^{*}$, G.A. Hortopan ${ }^{d}$, E. Plagnes-Juan ${ }^{\text {a, b, c }}$, C. Kolditz ${ }^{\text {a, b, c }}$, M. Lansard ${ }^{\text {a, b, c }}$, S. \\ Skiba-Cassy ${ }^{a, b, c}$, D. Esquerrée, I. Geurden ${ }^{a, b, c}$, F. Médale ${ }^{a, b, c}$, S. Kaushik ${ }^{a, b, c}$ and G.
} Corraze $^{a, b, c}$

\footnotetext{
a INRA, UMR1067 Nutrition Aquaculture et Génomique, F-64310 Saint-Pée-sur-Nivelle, France

b IFREMER, UMR1067 Nutrition Aquaculture et Génomique, F-29280 Plouzané, France

c Université Bordeaux 1, UMR 1067 Nutrition Aquaculture et Génomique, F-33405 Talence, France

${ }^{\mathrm{d}}$ Veterinary Medicine Faculty, Turin University, 10095 Grugliasco,Via L. da Vinci, 44, Turin, Italy

e INRA, DGA, UMR 1313 Génétique Animale et Biologie Intégrative, CRB GADIE, Jouy-en-Josas, F-78350 France
}

*: Corresponding author: S. Panserat, Tel.: +33 55951 59 60; fax: +33 5595451 52, email address : panserat@st-pee.inra.fr

\begin{abstract}
:
Our objective was to analyse the hepatic transcriptomes of juvenile rainbow trout fed with a plantbased diet. We focused our analysis on the total replacement of fish meal (FM) and fish oil (FO) by a $100 \%$ plant-based diet (0\% FM, 0\% FO). We analysed the postprandial hepatic transcriptomes of rainbow trout fed the two diets $8 \mathrm{~h}$ after feeding. Six total hepatic RNAs from each dietary group were hybridised against a trout cDNA microarray $(9 \mathrm{~K})$. After treatment of the data respecting the standard MIAME (Minimum Information About a Microarray Experiment) protocol, we found that 176 hepatic genes were differentially expressed between fish fed the two diets: 96 and 80 were over-expressed and under-expressed, respectively, in trout fed the plant-based diet. A large majority of differentially expressed genes were involved in metabolism (57\%) and the others in cellular processes $(21 \%)$ and transport $(10 \%)$. Among the genes involved in metabolism $(n=86), 37 \%$ were associated with protein metabolism (proteolysis, amino acid catabolism), $21 \%$ with lipid metabolism (fatty acid biosynthesis, cholesterol biosynthesis), 30\% with nucleic acid metabolism and $8 \%$ with glucose metabolism. Specifically, we found in rainbow trout fed the $100 \%$ plant diet an over-expression of genes involved in lipid biosynthesis (cholesterol metabolism and desaturation of polyunsaturated fatty acids) and an over-expression of a new metabolic actor, i.e., glycerol kinase which plays a key role at the interface of glucose-lipid metabolism. Overall, these data demonstrate that a number of intermediary metabolic effects occur in trout fed a totally plant-based diet.
\end{abstract}

Keywords: Marine ingredients; Vegetable products; Liver; Metabolism; Transcriptome; Rainbow trout 


\section{Introduction}

Feed for intensively farmed fish, still rely heavily on feedstuffs of marine origin, fish meal and fish oil (Tacon and Metian, 2008). Over the past 20 years, salmonids feeds have included large amounts of fish oil, given the beneficial effects on nitrogen utilisation and environmental loads (Cho and Kaushik, 1990; Sargent and Tacon, 1999). Such a high reliance on fish oil impairs the sustainability of fish farming (Naylor et al., 2000), while aquaculture is considered as a solution to the generally observed decline in fishery resources (FAO, 2006). Research is intense for finding ways to replace marine feedstuffs (fish meal and fish oil) by plant feedstuffs (Gatlin et al., 2007; Webster et al. 2007; Bell and Wagbo, 2008).

Efforts towards replacement of fish meal by other alternative protein sources have been undertaken since more than two decades and there is a vast amount of literature on partial replacement of fish meal by plant feedstuffs (Kaushik, 1990; Wesber and Lim, 2002; Gatlin et al., 2007; Webster et al. 2007). It is clear that a substantial reduction in the dietary levels of fish meal can be achieved although total replacement of fish meal by plant ingredients is still not common in salmonids (Watanabe et al., 1998, 1999). Some earlier studies have shown that total replacement of fish meal by plant proteins leads to decreased growth of rainbow trout (Onchorynchus mykiss) possibly linked to a modification of a number of hepatic metabolic pathways (Wilhelmsson et al., 2004).

With regard to fish oil, several studies with salmonids (rainbow trout, brown trout - Salmo trutta, Atlantic salmon - Salmo salar) have shown that it is possible to replace fish oil by single or a mixture of vegetable oils without affecting growth or feed efficiencies (Sargent and Tacon, 1999, Bell et al., 2003; Richard et al., 2006). Since the flesh fatty acid composition is known to be affected by the dietary fatty acid profiles, it is also known that once the fish are grown with vegetable oils over the major part of the life cycle, a finishing diet based on fish oil as the major lipid source must be used to tailor the final flesh fatty acid composition with the levels of n-3 polyunsaturated fatty acids (eicosapentaenoic acid (EPA) and docosahexaenoic acid (DHA) ideally suited for human nutrition and health (Bell et al., 2003; Glencross et al., 2003; Regost et al., 2003).

We and others have recently analysed hepatic gene expression variation linked to either fish oil or fish meal replacement in salmonids (Jordal et al., 2005; Panserat et al., 2008; Leaver et al., 2008). This approach suggested the existence of some hepatic genes being new molecular markers linked with the intake of the plant-based feeds. For example, the replacement of fish oil by vegetable oils was associated with modification of genes involved in cholesterol biosynthesis (Leaver et al., 2008) and fatty acid biosynthesis (Jordal et al., 2005); whereas, the substitution of fish meal by plant proteins was linked with decreased capacity of protein biosynthesis and variation in nitrogen metabolism (Panserat et al., 2008). However, the concomitant and complete replacement of fish oil and fish meal by plant products has never been undertaken up to now. The objective of the present study was thus to analyse the hepatic gene expression profile in rainbow trout (Oncorhynchus mykiss) fed with or without either fish oil or fish meal, replaced respectively by a mixture of oils or proteins of vegetable origin. Using a transcriptomic approach can be useful to find new molecular markers which could explain the lower growth in fish fed $100 \%$ plant products. We analysed specifically the liver since this is the main organ involved in nutrient utilisation as the centre of intermediary metabolism in animals. 


\section{Experimental procedures}

\subsection{Feeds, fish rearing and samplings}

Studies with animals were carried out in accordance with legislation governing the ethical treatment of animals, and investigators were certified by the French Government to carry out animal experiments (Authority: Prefecture of Pyrénées Atlantiques, 64000 Pau, for INRA St Pée-sur-Nivelle). Animal experiments were in accordance with national law Decret $\mathrm{n}^{\circ} 2001-$ 464 of May 29, 2001, as applicable in INRA according to note de service INRA $n^{\circ} 2002-36$, of April 4, 2002.

Juvenile rainbow trout (average weight $121 \pm 2 \mathrm{~g}$ ) were reared in the INRA experimental fish farm at constant water temperature $\left(17 \pm 1^{\circ} \mathrm{C}\right)$ and under natural photoperiod conditions (Donzacq, Landes, France). Fish were fed during 9.5 weeks with two isoproteic (around 45\% crude protein), isolipidic (around $27 \%$ crude fat) and isoenergetic (around $25 \mathrm{~kJ} / \mathrm{g}$ ) diets, differing by the lipid source; i.e., either fish oil or a mixture of vegetable oils (palm oil, linseed oil, rapeseed oil) and by the protein source; i.e., fish meal or a mixture of plant proteins (maize gluten, soybean seed and wheat gluten) (Table 1). The extruded feeds (Clextral B45, twin screw extrader) were produced in our feed unit (Donzacq, France).

Fish were randomly distributed into triplicate tanks per dietary treatment. Each diet was distributed by hand to visual satiation 6 days per week and feed consumption was recorded. After the 9.5-week trial, 25 representative fish of each dietary group linked to their mean size were selected to be unfed for 5 days and then fed once with their allocated diet, before being sacrificed $8 \mathrm{~h}$ after the meal. This fasting period contributed to homogenize the feed intake and the metabolic response of the fish within the same group and thus to obtain specifically a comparison between the effects of the two diets on the postprandial liver transcriptomes. The sampling at $8 \mathrm{~h}$ after feeding was chosen because we have previously shown that it corresponds to the postprandial peak of nutrient absorption for fish of this size at this water temperature (Panserat et al., 2002). Fish were sacrificed by a sharp blow on the head ; we carefully checked that fish ate well by visualizing stomach and intestinal contents. Livers were removed, weighed and immediately frozen in liquid nitrogen and kept at $-80^{\circ} \mathrm{C}$ pending analyses. Blood was removed from the caudal vein and centrifuged ( $3000 \mathrm{~g}, 5 \mathrm{~min})$, and the recovered plasma was immediately frozen and kept at $-20^{\circ} \mathrm{C}$ pending the analysis of plasma metabolites.

\subsection{Chemical composition of the diets}

The experimental diets were analyzed using the following procedures: dry matter after drying at $105^{\circ} \mathrm{C}$ for $24 \mathrm{~h}$, starch by the gluco-amylase glucose oxidase method (Thivend et al., 1972), and gross energy in an adiabatic bomb calorimeter (IKA, Heitersheim Gribheimer, Germany). Protein content (Nx6.25) was determined by the Kjeldahl method after acid digestion. Total lipid was determined by the method of Folch et al. (1957), after extraction by dichloromethane.

\subsection{Plasma metabolites}

Plasma glucose concentration was determined using the glucose oxidase method in a Beckman glucose analyser (Beckman II, USA). Plasma triacylglycerol levels were measured by colorimetric enzymatic assay using hepatic lipase (EC 3.1.1.3), glycerokinase (EC 2.7.1.30), glycerol-3-phosphate oxidase (EC 1.1.3.21) and peroxidase (EC 1.1.11) as enzymes (PAP 150 kit, Biomérieux, Marcy-l'étoile, France). Plasma free fatty acid levels were measured by colorimetric enzymatic assay using acyl-CoA synthetase, acyl-CoA 
oxydase and peroxydase as enzymes (Wako Nefa C kit, Wako chemicals GmbH, Neuss, Germany).

\section{4. cDNA microarrays}

Nylon microarrays were obtained from INRA-GADIE biological resources centre (http://www-crb.jouy.inra.fr/ ) (Jouy-en-Josas, France). A total of 9023 rainbow trout cDNAs originating from a pooled-tissue library (Govoroun et al., 2006) plus 193 controls were spotted after PCR amplification. PCR products were spotted onto Hybond $\mathrm{N}+$ membranes as described by Nguyen et al. (1995). Positive (plant luciferase cDNAs depot) and negative (water depot) controls were also spotted on each microarray.

\subsection{Hybridization. scanning and quantifications of microarrays}

Total RNAs were extracted from rainbow trout liver using TRIzol ${ }^{\circledR}$ reagent (Invitrogen. Carlsbad. CA. USA). Six hepatic RNA samples corresponding to six individuals per dietary group were used for microarray hybridisation at INRA UMR1067 transcriptomic facility (StPée-sur-Nivelle, France) according to the following procedure. RNA quality was determined using Agilent bioanalyser. A first hybridisation was performed at $42^{\circ} \mathrm{C}$ for $48 \mathrm{~h}$ using $\gamma^{33} \mathrm{P}$ labelled T7 promoter oligonucleotide (5'-CACTATAGGGAATTTGGCC-3') to estimate the amount of cDNA in each spot. After stripping $\left(3 \mathrm{~h} 68^{\circ} \mathrm{C}\right.$. $0.1 \mathrm{X}$ SSC. $\left.0.2 \% \mathrm{SDS}\right)$, hybridisations with hepatic cDNAs were performed. Microarrays were prehybridised for $1 \mathrm{~h}$ at $65^{\circ} \mathrm{C}$ in hybridisation buffer (5X Denhardt. 5X SSC, $0.5 \%$ SDS). Labelled cDNAs were prepared from $5 \mu \mathrm{g}$ of RNA by simultaneous reverse transcription and labelling for $1 \mathrm{~h}$ at $42^{\circ} \mathrm{C}$ in the presence of $50 \mu \mathrm{Ci}$ [alpha-33P] dCTP, $5 \mu \mathrm{M}$ cold dCTP and $800 \mu \mathrm{M}$ of each dATP, dGTP and dTTP and 200 units of SuperScript ${ }^{\text {TM }}$ III Reverse Transcriptase (Invitrogen, Carlsbad, CA, USA) in a final volume of $30 \mu \mathrm{L}$. A positive control corresponding to the luciferase mRNA (20 ng) (Promega, Madison, Wisconsin, USA) was simultaneously prepared. RNA was degraded by treatment at $68^{\circ} \mathrm{C}$ for 30 min with $1 \mu \mathrm{l} 10 \% \mathrm{SDS}, 1 \mu \mathrm{l} 0.5 \mathrm{M}$ EDTA and $3 \mu \mathrm{l} 3 \mathrm{M} \mathrm{NaOH}$. and then equilibrated at room temperature for $15 \mathrm{~min}$. Neutralisation was done by adding $10 \mu \mathrm{l} \mathrm{M}$ Tris- $\mathrm{HCl}$ and $3 \mu \mathrm{l} 2 \mathrm{~N} \mathrm{HCl}$. Microarrays were then incubated with the corresponding denatured labelled cDNA for $48 \mathrm{~h}$ at $65^{\circ} \mathrm{C}$ in hybridisation solution. After 3 washes $\left(1 \mathrm{~h} 68^{\circ} \mathrm{C}\right.$ with $0.1 \mathrm{X}$ SSC $0.2 \%$ SDS), microarrays were exposed for $65 \mathrm{~h}$ to phosphor-imaging plates that were scanned using a FUJI BASS 5000 (Ray-test France SARL). Signal intensities were quantified using AGScan software (bioinformatic platform Sigenae: http://www.sigenae.org/ ) (Lopez et al., 2004; Cathelin et al., 2007)

\subsection{Microarray data analysis}

Microarray data were deposited in BASE (BioArray Software Environment) database (Saal et al., 2002), a MIAME (Minimum Information About a Microarray Experiment) -supportive customisable database available at the bioinformatic platform Sigenae (http://www.sigenae.org/). Signal processing was performed using vector oligonucleotide data to correct the relative amount of DNA present in each spot. At this step, low nucleotide signals (less than 3 times the background level) were excluded from the analysis. After correction, signal was normalised by dividing each gene expression by the median value of the array before log transformation. Data were subsequently analysed using statistical TMEV (Tigr Multiple Experiment Viewer) software which is a suite of microarray data analysis applications (Saaed et al., 2003): variation of gene expressions between two dietary treatments was termed significant when the False Discovery Rate (FDR) value was $<10 \%$ using the SAM (statistical analysis of microarrays) procedure (Tusher et al., 2001; Pan, 2002) and followed by supervised hierarchical clustering for significant genes only. Organization of genes for biological interpretation in the context of Gene Ontology was 
performed using GoMiner software (http://discover.nci.nih.gov/gominer/ ) (Zeeberg et al., 2003).

\subsection{Data mining}

Rainbow trout sequences originating from INRA Agenae (Govoroun et al., 2006) and USDA (Rexroad et al., 2003) and EST sequencing programs were used to generate publicly available contigs (http://public-contigbrowser.sigenae.org:9090/index.html ). The $4^{\text {th }}$ version (om.4) was used for BlastX (Basic Local Alignment Search Tool) comparison (http://www.ncbi.nlm.nih.gov/blast/ ) with a cut-off value of 1e-05. The score of each alignment was retrieved after performing a Blast $\mathrm{X}$ comparison.

\subsection{Real time RT-PCR}

Gene expression levels were determined by real-time RT-PCR using the six RNA samples per dietary treatment included in the microarray analysis. One $\mu \mathrm{g}$ of total RNA was reverse transcribed to CDNA with the Superscript TM III RNAse $H$ Reverse Transcriptase kit (Invitrogen, Carlsbad, CA, USA) using oligo dT primers. Real-time PCR was performed in the iCycler iQ ${ }^{T M}$ (BIO-RAD, Hercules, CA, USA). Quantitative PCR (Q-PCR) analyses for gene expressions were performed on $10 \mu \mathrm{l}$ of the RT reaction mixture using the $\mathrm{iQ}^{\mathrm{TM}} \mathrm{SYBR}{ }^{\circledR}$ Green Supermix (BIO-RAD, Hercules, CA, USA). The total volume of the PCR reaction was $25 \mu \mathrm{l}$ containing $200 \mathrm{nM}$ of each primer. Primers were designed so that they were overlapping an intron when it was possible (Primer3 software; http://biotools.umassmed.edu/bioapps/primer3 www.cgi ) using known sequences in nucleotide databases: $\beta$-actin gene was amplified with the primer pair (5'GATGGGCCAGAAAGACACAGCTA-3') and (5'-TCGTCCCAGTTGGTGACGAT-3'), glycerol kinase gene using the primers (5'-GTTTGGCAGGAAGGTCGCTC-3') and (5'CAGCGCCTGTTCCCATCTCT-3') and $\triangle 6$-desaturase with the primer pair (5'AGGGTGCCTCTGCTAACTGG -3') and (5'-TGGTGTTGGTGATGGTAGGG -3').

Thermal cycling was initiated with the incubation at $95^{\circ} \mathrm{C}$ for $90 \mathrm{sec}$ for hot-start iTaq ${ }^{\mathrm{TM}} \mathrm{DNA}$ polymerase activation. Thirty five steps of PCR were performed, each one consisting of heating at $95^{\circ} \mathrm{C}$ for $20 \mathrm{~s}$ for denaturing, and at $59^{\circ} \mathrm{C}$ for $30 \mathrm{~s}$ for annealing and extension. Following the final cycle of the PCR, melting curves were systematically monitored (with a gradient of $0.5^{\circ} \mathrm{C} / 10 \mathrm{~s}$ from $55^{\circ} \mathrm{C}$ to $94^{\circ} \mathrm{C}$ ) to ensure that only one fragment was amplified. Samples without reverse transcriptase and samples without RNAs were run for each reaction as negative controls.

For the qRT-PCR data, significant differences were considered at $p<0.05$. Relative quantification of the target gene transcript with $\beta$ actin reference gene transcript was made following the Pfaffl method with the Relative Expression Software tool (REST@) (Pfaffl, 2001; Pfaffl et al., 2002). This mathematical algorithm computes an expression ratio, based on realtime PCR efficiency and the crossing point deviation of the unknown sample versus a control group: $\mathrm{R}=\left[\left(\mathrm{E}_{\text {target gene }}\right)^{\Delta \mathrm{CT}}\right.$ Target gene $\left.{ }^{\text {(mean control- mean unknown sample) }}\right] /\left[\left(\mathrm{E}_{\beta A c t i n}\right){ }_{\beta \text { Bactin }}\right.$ (mean control-mean unknown sample)] where $E$ is PCR efficiency determined by standard curve using serial dilution of cDNA (cDNA dilutions from $1 / 16$ up to $1 / 512$ ); $\triangle$ CT being the crossing point deviation of an unknown sample versus a control. Statistical differences in gene expression between control and sample were evaluated in group means by randomisation tests (Pfaffl, 2001; Pfaffl et al., 2002) using RESTC software. Two thousand random allocations were performed and significant differences were considered at $p<0.05$. 


\subsection{Statistical analysis}

Growth, efficiencies, feed intake and plasma metabolite parameters are presented as means \pm standard deviation. We analysed the effects of the different diets with an unpaired twotailed Student's t-test (Systat 9 software products, SPSS Inc).

\section{Results}

After 9.5 weeks of the feeding trial, rainbow trout fed with plant proteins and vegetable oils (plant diet) exhibited significantly lower growth rates, feed efficiency, protein efficiency and decreased feed intake than those fed with fish meal and fish oil (marine diet) $(p<0.05$, Student t-test) (Table 2). After a fasting period of 5 days followed by a successful refeeding, $8 \mathrm{~h}$ after this last meal, no significant differences were observed between dietary treatments ( $p>0.05$, Student t-test) for plasma metabolites (glucose, free fatty acids and triglycerides) (Table 2). Whereas the vsicero-somatic index was significantly modified (with a higher level of periviceral tissue in fish fed the plant diet (Table 2)), hepato-somatic index was unchanged between the dietary treatments (Table 2) allowing us to analyse the hepatic gene expression profiles. The analysis of the hepatic transcriptome showed that almost $2 \%$ of the genes were differentially expressed between fish fed the marine diet and those fed the plant diet (FDR $=5.45 \%$, SAM test; TMEV) with relatively low fold changes (between 1.2 and 1.5). Among the 176 genes differentially expressed between these two groups, a similar amount of genes exhibited higher $(n=96)$ and lower $(n=80)$ expression in fish fed plant diet.

Significance of the 176 differentially expressed gene expression profiling was evaluated using Gene Ontology analysis. Even though 30 genes had unknown identification (17\%), the other 146 genes were associated with biological annotation and were then clustered in functional groups as shown in Table 3 (GoMiner analysis). A large majority of the differentially expressed genes were involved in metabolism (57\%) and some in a lower proportion in cellular process (21\%) and in transport (10\%) (Tables 3, 4 and 5).

Concerning the cellular process, a major proportion of the genes was found to be involved in cell cycle regulation (such as those involved in apoptosis or cell movement); whereas, some nutrient (fatty acid, retinoid acid) transporters were expressed higher in fish fed the plant diet (Table 4).

Among the 83 genes linked with metabolism (Table 5), 57 genes (69\%) were associated with intermediary metabolism; 33 genes related to protein metabolism (37\%), 17 genes to lipid metabolism (21\%), and 7 genes to glucose metabolism (8\%) (Table 5). More precisely, in the group of genes coding for protein playing a role in protein metabolism, we observed some involved in proteolysis (calpain, carboxypeptidases A1) and protein-synthesis (ribosomal proteins, initiation factors) but none involved in amino acid catabolism or anabolism. However, no major groups of genes involved in nitrogen metabolism emerged clearly from the analysis. In the group of genes linked with lipid metabolism, we observed in fish fed the plant diet, an over-expression of genes involved in cholesterol metabolism (24dehydrocholesterol reductase precursor, C-4 methylsterol oxidase, 3-beta-hydroxysteroiddelta(8), delta(7)-isomerase), two genes involved in fatty acid beta-oxidation (3,2-transenoylCoA isomerase, trifunctional enzyme subunit), one key gene linked to desaturation of polyunsaturated fatty acid (Delta6/Delta5-desaturase) and one gene involved in glycerol metabolism (glycerol kinase; EC 2.7.1.30). Genes involved in lipid (sterol, phospholipid, glycerolipid) biosynthesis (dehydrogenase/reductase SDR family member; diacylglycerol kinase, acyl-coA:lysophosphophatidylglycerol acyltransferase) were largely represented in the under-expressed gene group of plant-fed fish. In the small group of glucose metabolism genes, some genes involved in glycolysis-gluconeogenesis (catalysing the first step of each 
of these metabolic pathways, i.e. glucose phosphorylation by hexokinase (EC 2.7.1.1) and phosphoenolpyruvate transformation to pyruvate by mitochondrial phosphoenolpyruvate carboxykinase (EC 4.1.1.32)) were expressed at a lower level in the plant-fed fish. Finally, $30 \%$ of the genes $(n=25)$ in the group of metabolism were found to be linked to nucleic acid metabolism; they coded mainly for transcriptional - nuclear- factors (playing a key role in transcription regulation not known to be related to nutritional regulation) and, as expected, some of them were either lower and higher expressed in fish fed the plant diet. Of these, only the peroxysome proliferator-activated receptor gamma co-activator 1-beta (PGC1 $\beta$ ) could play a role in the regulation of the intermediary metabolic pathway regulating potentially fatty acid beta-oxydation, gluconeogenesis and ketogenesis.

We focused the present study on two genes which can illustrate the intermediary metabolic pathway modified in rainbow trout liver by the diet variation. In this context, two genes involved in lipid metabolism ( $\Delta 6$-desaturase gene) and at the interface between lipid and glucose metabolism (glycerole kinase) have been selected. Using the same six individuals per dietary group and the quantitative RT-PCR, we confirmed that glycerol kinase and $\Delta 6$ desaturase were expressed higher by 2.6 and 4.1-fold, respectively, in fish fed the plant diet $(\mathrm{P}<0.05$; REST test).

\section{Discussion}

\subsection{Rainbow trout fed with $100 \%$ plant diet: diet and growth performance}

This study explored for the first time the effects of a concomitant replacement of dietary fish meal and fish oil by plant-based products in farmed salmonid. Even though intake of the $100 \%$ based-plant diet by juvenile rainbow trout was not associated with major problems involving fish health, fish mortality or fish deformities (our own observations), we observed lower growth performance of these fish which seems be due to a combination of a lower feed intake and a lower feed (protein) efficiency. We can hypothesize that the lower growth performance in fish fed plant products was mainly linked to the fish meal replacement and not to the fish oil substitution, as has been previously observed in this species (Kaushik et al., 1995; Watanabe et al., 1998; Richard et al., 2006; Panserat et al., 2008) and others (Watanabe et al., 1999; Kaushik et al., 2004; Gomez-Requeni et al., 2004). Recently, Torstensen et al. (2008) showed also decreased feed intake and growth depression in Atlantic salmon (Salmo salar) fed on combined replacement of fish meal and fish oil with plant meal and vegetable oil blends at $80 \%$ and $70 \%$ levels, respectively. Finally, the lower feed efficiency found in fish fed plant feedstuffs could be due to a poor metabolic adaptation of fish, especially in the liver which is the centre of intermediary metabolism and nutrient partitioning. Analysis of the hepatic transcriptome could detect either expected or unexpected molecular actors linked to the drastic modification of diet, as previously described in salmonids after diet modification (Jordal et al., 2005; Panserat et al., 2008, Kolditz et al., 2008, Leaver et al., 2008) but also in other physiological situations such as after the fastedfed status (Salem et al., 2007) and after hormonal (cortisol, growth hormone) treatment (Aluru and Vijayan, 2007; Gahr et al, 2008). We chose to establish a standard fastingrefeeding protocol. Even though this protocol could not allow us to strictly analyse the longterm effects of the two diets on the hepatic transcriptomes because these effects may be masked by the fasting stage (but not totally as reflected by the drastic variation of the $\Delta 6$ desaturase gene expression - linked to the nature of introduced oils - found in the present study), it had the advantages to homogenize the metabolic parameters before feeding and to obtain a constant feed intake regardless of the diet. This experimental design allowed us to analyse specifically the effect of the two diets on the postprandial hepatic transcriptomes. 


\subsection{Hepatic gene expression profiles linked to the total replacement of dietary marine resources in rainbow trout: general considerations}

This is the first ever analysis of the fish hepatic transcriptome after total replacement of marine ingredients (fish oil and fish meal) by $100 \%$ plant products. Our analysis of the hepatic transcriptomes revealed that less than 200 genes (of the 9000 genes of the multitissue library) were differentially expressed between the two groups $(<2 \%)$, which is a relatively low number of differentially expressed genes. However, the low number of differentially hepatic expressed genes linked to dietary composition confirmed what we had observed earlier in trout fed feeds with fish oil or fish meal substituted by plant oils or proteins using the same 9K trout microarray (Panserat et al., 2008). These results could be explained by the fact that, although the two diets differed in terms of ingredient origin (marine resources versus plant), they were isoproteic, isolipidic and isoenergetic. Interestingly, as generally observed in hepatic nutrigenomic studies (Swanson, 2008), the majority of the differentially expressed genes could be included into the functional group of (intermediary) metabolism (Table 5). Genes classified in the functional groups other than intermediary metabolism could be also interesting from a physiological point of view (such as the over-expression of some genes linked to the acquired immunity (immunoglobulin - Ig- genes) (Randelli et al., 2008) and of a group of cellular endocytosis and trafficking proteins (e.g. sortin nexin genes) (Worby and Dixon, 2002) as well as the under expression of genes involved in intracellular transport along cytoskeletal tracks such as kinesin and dynein genes (Vale, 2003) in fish fed the $100 \%$ plant diet. However, we focus our discussion on the differentially expressed actors of intermediary metabolism from the nutrigenomic point of view.

\subsection{Effects on intermediary metabolism}

The actors linked with protein metabolism constituted the largest group showing differential gene expressions between the two groups; this could be related to the high protein requirement of rainbow trout and thus a higher sensitivity of these fish to changes in dietary protein quality (Cowey and Walton, 1989). However, it was not very easy to determine precisely a specific - up or down - regulated protein metabolic pathway in fish fed the $100 \%$ plant diet; some of these actors in different proteolytic systems were induced (calpain, carboxypeptidase, dipeptidase, 26S proteasome subunit) but for the actors involved in protein synthesis, some were induced (ribosomal proteins L36 and S26) and the others diminished (two translation initiation factors). These results are somewhat in contrast to our previous transcriptomic studies clearly showing a down regulation of a large number of ribosomal actors (10 ribosomal proteins involved in proteosynthesis) in fish fed plant proteins compared to fish fed fish meal (Panserat et al., 2008). Two major reasons to explain this discordance could be (i) the combined effect of low essential fatty acid level (found mainly in fish oil) along with a change in amino acid profile (due to the fish meal replacement) which had never been tested before and (ii) the experimental fasting-refeeding design which could have masked some of the effects at long term observed previously (Panserat et al., 2008). Our data suggest also a decrease in hepatic glucose metabolism as reflected by lower gene expression of hexokinase and phosphoenolpyruvate carboxykinase enzymes respectively catalyzing the first steps of glycolysis and gluconeogenesis (Pilkis and Granner, 1992). The variation of hexokinase and phosphoenolpyruvate carboxykinase gene expression was unexpected due to the similar dietary carbohydrate levels in all diets (almost 10\%) and the well known poor control of these two enzymes by feeding in fish (Panserat et al., 2000, 2001). However, since a number of other glucose enzymes and other types of regulation (phosphorylation, allostery) play key roles in dietary carbohydrate use in the liver, biological significance of the observed changes in glucose gene expression is limited. 
At the level of lipid metabolism, data are interesting, confirming some previous observations and discovering potential molecular markers linked to plant ingredient incorporation. Firstly, we confirmed some of the earlier data obtained after substitution of fish oil by vegetable oils in Atlantic salmon (Leaver et al., 2008): we observed higher levels of gene expression of enzymes involved in cholesterol biosynthesis and in the fatty acid desaturation process in fish fed the $100 \%$ plant diet, suggesting a potential alteration of the lipid biosynthetic pathway in the liver. The induction of the desaturation metabolic pathway (as confirmed by a 6 -fold induction of $\triangle 6$-desaturase mRNA level by real-time PCR) could be easily explained by the replacement of fish oil (rich in n-3 long-chain unsaturated fatty acids known to be strong inhibitors of $\Delta 6$-desaturase gene expression) by vegetable oils (poor in $n-3$ long-chain unsaturated fatty acids), as was shown in rainbow trout liver (Seiliez et al., 2001). The increase of $\Delta 6$-desaturase gene expression could be also amplified by the concomitant suppression of fish oil and fish meal (containing $8 \%$ of lipids) which results in a diet almost devoid of n-3 long-chain unsaturated fatty acids. The positive effects on genes of the cholesterol biosynthesis pathway reveal that fish fed the plant diet were able to respond to reduced dietary cholesterol levels in the plant diet (presently the levels of cholesterol were $5.2 \%$ versus $3 \%$ of dry matter for marine and plant diets, respectively; G Corraze personal communication). Secondly, on the other hand, we found a drastic molecular induction of a new metabolic marker, i.e., the hepatic glycerol kinase, in fish fed the plant diet (3-fold induction as tested by real-time PCR). Glycerol kinase is an important enzyme at the interface of carbohydrate and lipid metabolism, catalyzing the inter-conversion of glycerol and glycerol 3-phosphate, the latter being necessary for re-esterification with fatty acids for lipid (triglyceride) biosynthesis (Dipple et al., 2001). However, the concomitant low level of lysophosphatidylglycerol acyltransferase gene expression (Table 5) does not reinforce the possibility of the existence of a higher capacity of lipid biosynthesis in trout liver. In mammals, it is known that over-expression of glycerol kinase enzyme induces the de novo biosynthesis of lipids (Sriram et al., 2008); therefore, the over-expression of glycerol kinase in fish fed plant products could be linked to the higher level of lipid found in the viscera of these fish (Table 2).

\subsection{Perspectives about the use of transcriptomics data to help the development of novel aquafeeds}

In the present paper, our major objective using a transcriptomic approach was to discover potential hepatic molecular markers associated with fish fed $100 \%$ plant products, even though our data corresponded to a "single snapshot" of gene expression profile (Leaver et al., 2008; Robinson et al., 2008) after a fasting-refeeding experimental design. In spite of this, our data suggest variations of intermediary metabolism which were either expected (for enzymes involved in the cholesterol and fatty acid biosynthesis for example) or unexpected (for the new marker glycerol kinase); both of these variations could modify nutrient utilization and partitioning.

In conclusion, although total removal of ingredients of marine origin is not essential for sustainable aquaculture development (Tacon and Metian, 2008), knowledge on potential implications of such extreme diets is useful: because no major dysfunction of hepatic metabolism (fish health), no over-expression of hepatic genes involved in stress and welfare (in contrast to what has been previously observed by Wilhelmsson et al., 2004), and no strong variation of hepatic cell cycle actors such as those involved in apoptosis were found in this study, our data could be interpreted as a weak effect of complete changes in diet ingredient inclusion on the liver. This result is encouraging in the context of the development of new aquafeeds. However, more in-depth research is warranted for evaluating the potential changes due to individual nutrients and their levels. Integrative biological approaches as used here are useful for evaluating novel ingredients and for developing potential biomarkers associated with the use of novel feeds. 


\section{Acknowledgements}

We acknowledge MJ Borthaire for her excellent technical assistance. We thank F. Terrier. Y. Hontang and F. Sandres for rearing fish in INRA experimental farm (Donzacq, Landes, France).

\section{Sources of funding}

This work was financed by $6^{\text {th }}$ PCRD European project (contract $n^{\circ} 016249-2$, Sustainable Aquafeeds to Maximise the Health Benefits of Farmed Fish for Consumers (AQUAMAX)). This work was also supported by an EU grant (AQUAMAX project) for M. Lansard.

\section{References}

Aluru N, Vijayan MM. (2007) Hepatic transcriptome response to glucocorticoid receptor activation in rainbow trout. Physiol Genomics. 31(3):483-91.

Bell JG, Tocher DR, Henderson RJ, Dick JR, \& Crampton VO. (2003) Altered fatty acid compositions in Atlantic salmon (Salmo salar) fed diets containing linseed and rapeseed oils can be partially restored by a subsequent fish oil finishing diet. J. Nutr. 133(9):2793-801.

Bell JG \& Waagbo R (2008) Safe and Nutritious Aquaculture Produce: Benefits and Risks of Alternative Sustainable Aquafeeds. In: Aquaculture in the Ecosystem (ed. by Holmer M, Black K, Duarte C, Marba N, Karakassis I). Kluwer Academic Publishers Group, pp. 185225.

Cathelin R, Lopez F \& Klopp C (2007) AGScan: a pluggable microarray image quantification software based on the ImageJ library. Bioinformatics 23(2):247-8.

Cho C. \& Kaushik SJ (1990) Nutritional energetics in fish: energy and protein utilization in rainbow trout (Salmo gairdneri). World Rev. Nutr. Diet. 61: 132-172.

Cowey C. \& Walton M. (1989) Intermediary metabolism. In: Intermediary Metabolism (Cowey, C. \& Walton, M., eds.), pp. 259-329. Academic Press, New York.

Dipple KM, Zhang YH, Huang BL, McCabe LL, Dallongeville J, Inokuchi T, Kimura M, Marx HJ, Roederer GO, Shih V, Yamaguchi S, Yoshida I, McCabe ER. (2001) Glycerol kinase deficiency: evidence for the complexity in a single gene disorder. Hum. Genet. 55-62.

F.A.O. Food and Agricultural Organization (2006) State of world aquaculture. ftp://ftp.fao.org/docrep/fao/009/a0874e/a0874e00.pdf.

Folch J, Lees M Sloane M \& Stanley GH (1957) A simple method for the isolation and purification of total lipids from animal tissues. J. Biol. Chem. 226(1):497-509.

Gahr SA, Vallejo RL, Weber GM, Shepherd BS, Silverstein JT, \& Rexroad CE 3rd. (2008) Effects of short-term growth hormone treatment on liver and muscle transcriptomes in rainbow trout (Oncorhynchus mykiss). Physiol Genomics. 32(3):380-92.

Gatlin III DM, Barrows FT, Brown P et al. (2007) Expanding the utilization of sustainable plant products in aquafeeds: a review. Aquaculture Res 38: 551-579. 
Glencross BD, Hawkins WE \& Curnow JG (2003) Restoration of the fatty acid composition of redseabream (Pagrus auratus) using a fish oil finishing diet after growth-out on plant based diet. Aquaculture Nutr. 9(6): 409-418.

Gomez-Requeni P, Mingarro M., Calduch-Giner JA, Medale F, Martin SAM, Houlihan DF, Kaushik S, \& Perez-Sanchez J. (2004) Protein growth performance, amino acid utilisation and somatotropic axis responsiveness to fish meal replacement by plant protein sources in gilthead sea bream (Sparus aurata). Aquaculture 232: 493-510.

Govoroun M, Le Gac F, \& Guiguen Y (2006) Generation of a large scale repertoire of expressed sequences tags (ESTs) from normalised rainbow trout cDNA libraries. BMC Genomics 7: 196-203.

Jordal AO, Torstensen, BE, Tsoi, S., Tocher, DR, Lall SP, \& Douglas SE (2005) Dietary rapeseed oil affects the expression of genes involved in hepatic lipid metabolism in Atlantic salmon (Salmo salar). J. Nutr 135(10): 2355-2361.

Kaushik SJ (1990). Use of alternative protein sources for the intensive rearing of carnivorous fishes. In: Mediterranean Aquaculture, (R. Flos, L.Tort \& P. Torres, eds), Ellis Horwood, UK. pp 125-138.

Kaushik SJ, Coves D, Dutto G, \& Blanc D (2004). Almost total replacement of fishmeal by plant protein sources in the diets for European seabass (Dicentrarchus labrax). Aquaculture 230: 391-404.

Kaushik SJ, Cravedi JP, Lalles JP, Sumpter J, Fauconneau B \& Laroche M (1995) Partial or total replacement of fish meal by soybean proteins on growth, protein utilization, potential oestrogenic or antigenic effects, cholesterolemia and flesh quality in rainbow trout. Aquaculture 133: 257-274.

Kolditz C, Paboeuf G, Borthaire M, Esquerre D, Sancristobal M, Lefevre F, \& Medale F. (2008) Changes induced by dietary energy intake and divergent selection for muscle fat content in rainbow trout (Oncorhynchus mykiss), assessed by transcriptome and proteome analysis of the liver. BMC Genomics. 9(1):506.

Leaver MJ, Villeneuve LAN, Obach A., Jensen L., Bron J.E., Tocher D. R., \& Taggart J/B. (2008) Functional genomics reveals increases in cholesterol biosynthetic genes and highly unsaturated fatty acid biosynthesis after dietary substitution of fish oil with vegetables oils in Atlantic salmon (Salmo salar). BMC Genomics. 9: 299

Lopez F, Rougemont J, Loriod B, Bourgeois A, Loi L, Bertucci F, Hingamp P, Houlgatte R \& Granjeaud S (2004) Feature extraction and signal processing for nylon DNA microarrays. BMC Genomics. 5(1):38.

Naylor RL, Goldberg RJ, Primavera JH, Kautsky N, Beveridge MCM, Clay J, Folke, C., Libchenko, J., Mooney, H. \& Troell, M. (2000) Effect of aquaculture on world fish supplies. Nature 405: 1017-1024

Nguyen C, Rocha D, Granjeaud S, Baldif M., Bernard K., Naquet P., \& Jordan B. (1995) Differential gene expression in the murine thymus assayed by quantitative hybridization of arrayed cDNA clones. Genomics 29(1): 207-16.

Pan W (2002) A comparative review of statistical methods for discovering differentially expressed genes in replicate microarray experiments. Bioinformatics 21(15): 546-554 
Panserat S, Médale F, Blin C, Brèque J, Vachot C, Plagnes-Juan E, Krishnamoorthy R, \& Kaushik S. (2000) Hepatic glucokinase is induced by dietary carbohydrates in rainbow trout (Oncorhynchus mykiss), common carp (Cyprinus carpio) and gilthead seabream (Sparus aurata). Am J. Physiol. - Regul. Int. Comp. Physio. 278 : R1164-1170

Panserat S, Plagnes-Juan E, Breque J, \& Kaushik S (2001). Hepatic phosphoenolpyruvate carboxykinase gene expression is not repressed by dietary carbohydrates in rainbow trout (Oncorhynchus mykiss). J. exp. Biol. 204: 359-365.

Panserat S, Perrin A, \& Kaushik S 2002. High dietary lipids induce liver glucose-6phosphatase expression in rainbow trout (Oncorhynchus mykiss). J. Nutr. 132: 137141.

Panserat S, Kolditz C, Richard N, Plagnes-Juan E, Piumi F., Esquerré D., Médale F., Corrze G., \& Kaushik S (2008) Hepatic gene expression profiles in rainbow trout (Oncorhynchus mykiss) fed fish meal or fish oil-free diets. Br. J. Nutr. 100(5):953-67.

Pfaffl MW. (2001) A new mathematical model for relative quantification in real-time RT-PCR. Nucl Acids Res 29: E45-E45.

Pfaffl MW, Horgan GW, Dempfle L. (2002) Relative expression software tool (RESTC) for group-wise comparison and statistical analysis of relative expression results in real-time PCR. Nucl Acids Res. 30: 9-36.

Pilkis SJ \& Granner DK. (1992) Molecular physiology of the regulation of hepatic gluconeogenesis and glycolysis. Ann. Rev. Physiol. 54: 885-909.

Randelli E, Buonocore F and Scapigliati G (2008) Cell markers and determinants in fish immunology. Fish Shell. Immunol. 25: 326-340.

Regost C, Arzel J, Robin G, Rosenlund G \& Kaushik SJ (2003) Total replacement of fish oil by soybean or linseed oil with a return to fish oil in turbot (Psetta maxima). Aquaculture 220: 737-747.

Rexroad CE, Lee Y, Keele JW, Karamycheva S, Brown G, Koop B, Harg SA, Palti Y, \& Quackenbush J (2003) Sequence analysis of a rainbow trout cDNA library and creation of a gene index. Cyt. Gen Res 102: 347-354.

Richard N, Kaushik S, Larroquet L, Panserat S \& Corraze G (2006) Replacing dietary fish oil by vegetable oils has little effect on lipogenesis, lipid transport and tissue lipid uptake in rainbow trout (Oncorhynchus mykiss). Br. J. Nutr. 96: 299-309.

Robinson N., Goddard M., \& Hayes B. (2008) Use of gene expression data for predicting continuous phenotypes for animal production and breeding. Animal 2:10: 1413-1420.

Saal LH, Troein C, Vallon-Christersson J, Gruvberger S, Borg A \& Peterson C (2002) Bioarray software environment (BASE) : a platform for comprehensive management and analysis of microarray data. Genome Biol. 3(8): software0003.1-0003.6.

Saeed Al, Sharov V, White J, Li J, Liang W, Bhagabati N, Braisted J, Klapa M, Currier T, Thiagarajan M, Sturn A, Snuffin M, Rezantsev A, Popov D, Ryltsov A, Kostukovich E, Borisovsky I, Liu Z, Vinsavich A, Trush V, Quackenbush J. (2003) TM4: a free, open-source system for microarray data management and analysis. Biotechniques 34(2):374-8 
Salem M, Silverstein J, Rexroad CE 3rd, \& Yao J. (2007) Effect of starvation on global gene expression and proteolysis in rainbow trout (Oncorhynchus mykiss). BMC Genomics 8: 328.

Sargent JR \& Tacon AGJ (1999) Development of farmed fish: a nutritionally necessary alternative to meat. Proc. Nutr. Soc. 58(2):377-83.

Seiliez I., Panserat S., Kaushik S., \& Bergot P. (2001) Cloning, tissue distribution and nutritional regulation of a delta-6-desaturase-like enzyme in rainbow trout. Comp. Biochem. Physiol. B- Biochem. Mol. Biol. 130 : 83-93.

Sriram S., Rahib L., He JS, Campos AE, Oarr LS, Liao JC, \& Dipple KM (2008) Global metabolic effects of glycerol kinase overexpression in rat hepatoma cells. Mol. Genet. Metab. 93: $145-159$.

Swanson KS. (2008) Using genomic biology to study liver metabolism. J Anim Physiol Anim Nutr (Berl). 92(3):246-52.

Tacon AGJ \& Metian M (2008) Global overview of the fish meal and fish oil in industrially coumpounded aquafeeds: trend and future prospects. Aquaculture 285: 146-158.

Thivend, P, Mercier, C, Guilbot, A (1972) Determination of starch with glucoamylase. In: Whistler, R.L., Bemiller, J.N. (Eds.), Methods in Carbohydrate Chemistry, Vol VI, Academic Press, New York, pp. 100-105.

Torstensen BE, (2008) Novel production of Atlantic salmon (Salmo salar) protein based on combined replacement of fish meal and fish oil with plant meal and vegetable oil blends. Aquaculture 285: 193-200.

Tusher VG, Tibshirani R, \& Chu G. (2001) Significance analysis of microarrays applied to the ionizing radiation response. Proc Natl Acad Sci U S A. 98(9):5116-21

Vale RD (2003) The molecular motor toolbox for intracellular transport. Cell 112: 467480.

Vilhelmsson OT, Martin SAM, Medale F, Kaushik SJ, \& Houlihan DF (2004) Dietary plant protein substitution affects hepatic metabolism in rainbow trout. Br. J. Nutr. 92:71-80.

Watanabe T, Verakunpiriya V, Watanabe K, Viswanath, K, \& Satoh S (1998). Feeding of rainbow trout with non-fish meal diets. Fisheries Sci. 63:258-266

Watanabe T, Aoki H, Shimamoto K, Hadzuma M, Maita M,Yamagata Y, Viswanath K, \& Satoh S (1999). A trial to culture yellowtail with non-fishmeal diets. Fisheries Sci. 64: 505-512

Webster, C., Lim, C., \& Lee S-C., (2007). Use of alternative protein sources in aquaculture diets. The Haworth Press, Inc, NY, USA, 626p.

Worby CA \& Dixon JE (2002) Sorting out the cellular functions of sorting nexins. Nature Rev. Mol. Cell. Biol. 3: 919-931.

Zeeberg BR, Feng W, Wang G, Wang MD, Fojo AT, Sunshine M, Narasimhan S, Kane DW, Reinhold WC, Lababidi S, Bussey KJ, Riss J, Barrett JC, \& Weinstein JN. (2003) GoMiner: a resource for biological interpretation of genomic and proteomic data. Genome Biol. 4(4):R28. 
Table 1. Composition of the two experimental diets.

\begin{tabular}{|c|c|c|}
\hline & $\begin{array}{l}\text { Marine } \\
\text { diet }\end{array}$ & $\begin{array}{l}\text { Plant } \\
\text { diet }\end{array}$ \\
\hline \multicolumn{3}{|l|}{ Ingredients (\%) } \\
\hline Fish meal LT (CP 70\%) ${ }^{1}$ & 59 & - \\
\hline Corn gluten meal (CP 57\%) ${ }^{2}$ & - & 20 \\
\hline Soybean meal $(\mathrm{CP} 46 \%)^{2}$ & - & 15.4 \\
\hline Wheat gluten (CP 78\%) ${ }^{3}$ & - & 26 \\
\hline Corn $^{4}$ & 7 & 7 \\
\hline Extruded whole wheat $^{2}$ & 12 & 0.1 \\
\hline Fish oil ${ }^{1}$ & 19 & - \\
\hline Rapeseed oil ${ }^{5}$ & - & 11.6 \\
\hline Linseed oil ${ }^{5}$ & - & 4.6 \\
\hline Palm oil ${ }^{5}$ & - & 7 \\
\hline Soybean lecithin ${ }^{6}$ & - & 1 \\
\hline L-lysine ${ }^{7}$ & - & 1.2 \\
\hline L-arginine ${ }^{7}$ & - & 0.1 \\
\hline CaHPO4-2H2O (18\%P) & - & 3 \\
\hline Astaxanthine $^{8}$ & 0.03 & 0.03 \\
\hline Mineral premix ${ }^{9}$ & 1 & 1 \\
\hline Vitamin Premix ${ }^{10}$ & 1 & 1 \\
\hline \multicolumn{3}{|l|}{ Analytical composition } \\
\hline Dry matter (\%DM) & 94.1 & 90.9 \\
\hline Crude protein (CP, \% DM) & 45.9 & 44.4 \\
\hline Crude fat (\% DM) & 26.6 & 27.8 \\
\hline Crude starch (\% DM) & 12.1 & 11.3 \\
\hline Gross energy (kJ/g DM) & 24.1 & 25.7 \\
\hline
\end{tabular}

1. Sopropêche, Lorient, France

2. Inzo, Argentan, France

3. Roquette, Lestrem, France

4. Lacadee Agro Industrie, Mont, France

5. Daudruy, Dunkerque, France

6. Louis François, Saint Maur, France

7. Eurolysine, Paris, France

8. Carophyll pink, DSM, Courbevoie, France

*9. Supplied the following ( $\mathrm{mg} / \mathrm{kg}$ diet, except as noted): calcium carbonate (40\% Ca) 2.15 $\mathrm{g}$, magnesium hydroxide $(60 \% \mathrm{Mg}) 1.24 \mathrm{~g}$, potassium chloride $0.9 \mathrm{~g}$, ferric citrate $0.2 \mathrm{~g}$, potassium iodine $4 \mathrm{mg}$, sodium chloride $0.4 \mathrm{~g}$, calcium hydrogen phosphate $50 \mathrm{~g}$, copper 
sulphate $0 \cdot 3$, zinc sulphate 40 , cobalt sulphate 2 , manganese sulphate 30 , sodium selenite 0.3 .

10. Supplied the following ( $\mathrm{mg} / \mathrm{kg}$ diet): retinyl acetate 2.58 , DL-cholecalciferol 0.037 , DL$\alpha$ tocopheryl acetate 30 , menadione sodium bisulphite 2.5 , thiamin 7.5 , riboflavin 15 , pyridoxine $7 \cdot 5$, nicotinic acid 87.5 , folic acid 2.5 , calcium pantothenate 2.5 , vitamin $B_{12} 0.025$, ascorbic acid 250, inositol 500, biotin 1.25 and choline chloride 500 .

Table 2. Effects of fish oil and fish meal replacement on growth performance, feed efficiency, feed intake and plasma parameters in juvenile rainbow trout (initial body weight (IBW) = $121 \mathrm{~g})$. Data are expressed as means \pm standard deviation (SD) ( $\mathrm{n}=3$ tanks). The plasma parameters were measured after the long-term feeding trial ( 9.5 weeks) followed by a fasting-refeeding sequence ( $\mathrm{n}=8$ fish per diet). N.S: no significant differences between groups ( $p>0.05$, t-test Student).

\begin{tabular}{|c|c|c|c|c|c|}
\hline & $\begin{array}{l}\text { Fish fed } \\
\text { Mean }\end{array}$ & $\begin{array}{l}\text { Marine diet } \\
\text { SD }\end{array}$ & $\begin{array}{l}\text { Fish fed } \\
\text { Mean }\end{array}$ & $\begin{array}{l}\text { Plant diet } \\
\text { SD }\end{array}$ & P-values \\
\hline \multicolumn{6}{|l|}{$\begin{array}{l}\text { Zootechnical } \\
\text { parameters }\end{array}$} \\
\hline $\begin{array}{l}\text { Final body weight } \\
\text { (FBW) (g) }\end{array}$ & 509.1 & 7.1 & 427.2 & 2.8 & 0.00005 \\
\hline Daily Growth Index ${ }^{1}$ & 4.52 & 0.08 & 3.84 & 0.05 & 0.0002 \\
\hline Feed Efficiency ${ }^{2}$ & 1.08 & 0.02 & 0.94 & 0.01 & 0.0005 \\
\hline $\begin{array}{l}\text { Protein Efficiency } \\
\text { Ratio }^{3}\end{array}$ & 2.49 & 0.04 & 2.33 & 0.03 & 0.007 \\
\hline $\begin{array}{l}\text { Feed Intake } \\
\text { Index }\end{array}$ & 5.45 & 0.13 & 4.94 & 0.04 & 0.003 \\
\hline $\mathrm{HSI}^{5}$ & 1.1 & 0.1 & 1.0 & 0.1 & NS \\
\hline $\mathrm{VSI}^{6}$ & 9.2 & 1.7 & 10.9 & 1.9 & $P<0.05$ \\
\hline \multicolumn{6}{|l|}{$\begin{array}{l}\text { Plasmatic parameters } \\
\text { (8h after feeding) }\end{array}$} \\
\hline Glycemia (g/l) & 1.09 & 0.27 & 1.39 & 0.4 & N.S \\
\hline $\begin{array}{l}\text { Free fatty acids } \\
(\mathrm{mEq} / \mathrm{l})\end{array}$ & 0.27 & 0.07 & 0.24 & 0.02 & N.S \\
\hline Triglycerides (g/l) & 2.27 & 1.34 & 2.03 & 0.87 & N.S \\
\hline
\end{tabular}


Table 3. Global repartition of the $n=146$ (annotated) differentially expressed hepatic genes between fish fed the two experimental marine and plant diets $8 \mathrm{~h}$ after the last meal $(\mathrm{n}=6$ individuals per group). These data were extracted after statistical analysis of microarrays $(F D R=5.45 \%)$ for detection of differentially expressed genes and then from gene ontology analysis (GoMiner) for clustering differentially expressed genes by function.

\begin{tabular}{cccc}
\hline $\begin{array}{c}\text { Pathways and } \\
\text { biological } \\
\text { function }\end{array}$ & $\begin{array}{c}\text { Differentially } \\
\text { expressed } \\
\text { genes (\%) }\end{array}$ & $\begin{array}{c}\text { Up-regulated } \\
\text { genes in fish fed } \\
\text { plant diet }\end{array}$ & $\begin{array}{c}\text { Down-regulated } \\
\text { genes in fish fed } \\
\text { plant diet }\end{array}$ \\
\hline Metabolism : & $84(57.5 \%):$ & 48 & 36 \\
- Protein & 33 & 19 & 14 \\
- Lipid & 17 & 11 & 6 \\
- Glucose & 7 & 2 & 5 \\
- Nucleic Acid & 25 & 14 & 11 \\
- Others & 4 & 2 & 2 \\
Cellular Process : & $30(20.5 \%)$ & 14 & 16 \\
- Cell Cycle & 11 & & \\
- Apoptosis & 6 & & \\
- Biogenesis & 2 & & \\
- Cell & 6 & & \\
Communication & 3 & & \\
- Cell Adhesion & 2 & & \\
- Others & & & \\
Transport & $14(9,6 \%)$ & & \\
Others & $18(12,4 \%)$ & & \\
\hline
\end{tabular}


Table 4. Functional groups (except the metabolic group detailed in Table 5) of hepatic transcripts exhibiting lower (italic letters) or higher (normal letters) abundance in fish fed the $100 \%$ plant diet $8 \mathrm{~h}$ after the last meal ( $\mathrm{n}=6$ individuals per group). These data were extracted after statistical analysis of microarrays (FDR $=5.45 \%$ ) for detection of differentially expressed genes and then from gene ontology analysis (GoMiner) for clustering genes by function. + and - regulation means that the target gene is expressed at a lower or higher level, respectively.

\begin{tabular}{|c|c|c|c|}
\hline Biological Process & Swissprot-hit-description & 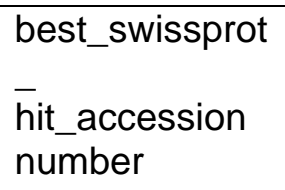 & $\begin{array}{l}\text { Fold- } \\
\text { change } \\
\text { s }\end{array}$ \\
\hline \multicolumn{4}{|l|}{ Cellular process } \\
\hline & Nuclear-associated protein) (NAP) & CTBL1_HUMAN & +1.4 \\
\hline & Programmed cell death protein 6 & PDCD6 MOUSE & +1.2 \\
\hline & $\begin{array}{l}\text { Pleckstrin homology-like domain family A member } 2 \text { (Tumor- } \\
\text { suppressing STF cDNA } 3 \text { protein) }\end{array}$ & PHLA2_HUMAN & +1.2 \\
\hline & Apoptosis response zinc finger protein & REQU_MOUSE & +1.4 \\
\hline & RING finger protein 122 & RN122_MOUSE & +1.2 \\
\hline & Protocadherin alpha 7 precursor (PCDH-alpha7) & PCDA7_HUMAN & +1.2 \\
\hline & GEM-interacting protein (GMIP) & GMIP_HUMAN & +1.3 \\
\hline & Tensin & TENS_CHICK & +1.4 \\
\hline & WD repeat protein 12 (YTM1 homolog) & WDR12_HUMAN & +1.2 \\
\hline & Condensin complex subunit 3 & CND3_XENLA & +1.2 \\
\hline & Histone H5A & H5A_XENLA & +1.4 \\
\hline & Kinesin-like protein KIF3B & KIF3B_MOUSE & +1.3 \\
\hline & Kinetochore protein Hec1 homolog & KNTC2_BRARE & +1.3 \\
\hline & Thioredoxin-like protein 4A & TXN4A_MOUSE & +1.4 \\
\hline & Poly [ADP-ribose] polymerase 4 (EC 2.4.2.30) (PARP-4) & PARP4_HUMAN & -1.2 \\
\hline & Dynein intermediate chain 2, axonemal & DNAI2_HUMAN & -1.2 \\
\hline & Four and a half LIM domains protein 3 & FHL3_MOUSE & -1.3 \\
\hline & Cadherin-11 precursor (Osteoblast-cadherin) & CAD11_HUMAN & -1.4 \\
\hline & Zonadhesin (Fragment) & $Z A N \_R A B I T$ & -1.2 \\
\hline & Neogenin (Fragment) & NEO1_CHICK & -1.2 \\
\hline & Calcium-binding protein 1 (CaBP1) (Caldendrin) & CABP1_RAT & -1.3 \\
\hline & Insulin receptor substrate 1 (IRS-1) (pp185) & IRS1_RAT & -1.3 \\
\hline & Lysophosphatidic acid receptor LPA1 homolog 2 (XLPA1-2) & LPA12_XENLA & -1.3 \\
\hline & Kinesin-like protein KIF22 & KIF22_HUMAN & -1.3 \\
\hline & Kinesin-like protein KIF2C & KIF2C_CRIGR & -1.2 \\
\hline & Microtubule-associated protein RP/EB family member 1 & MARE1_XENTR & -1.3 \\
\hline & Transforming growth factor beta-2 precursor (TGF-beta-2) & TGFB2_XENLA & -1.3 \\
\hline & Cytospin-A & CYTSA_BRARE & -1.2 \\
\hline & Annexin A13 & ANX13_HUMAN & -1.2 \\
\hline & Retinoblastoma-binding protein 9 (RBBP-9) & $R B B P 9 \_R A T$ & -1.2 \\
\hline \multicolumn{4}{|l|}{ Transport } \\
\hline & Fatty acid-binding protein, heart (H-FABP) & FABPH_ONCMY & +1.2 \\
\hline & Hemopexin precursor (Beta-1B-glycoprotein) & HEMO_HUMAN & +1.3 \\
\hline & Nucleoporin NUP53 & NUP53_BRARE & +1.2 \\
\hline & Retinoid-binding protein 7 (CRBP4) & RET7_MOUSE & +1.3 \\
\hline & Selenium-binding protein 1 & SBP1_HUMAN & +1.3 \\
\hline & Vesicle-trafficking protein SEC22a & SC22A_HUMAN & +1.3 \\
\hline & Sorting nexin-11 & SNX11_HUMAN & +1.2 \\
\hline & Sorting nexin-24 & SNX24_HUMAN & +1.4 \\
\hline
\end{tabular}




\begin{tabular}{|c|c|c|c|}
\hline \multirow{24}{*}{ Other functions } & Syntaxin-2 (Epimorphin) & STX2_HUMAN & +1.3 \\
\hline & Voltage-dependent anion-selective channel protein 3 (VDAC-3) & VDAC3_RABIT & +1.3 \\
\hline & Metaxin-1 & MTX1_MOUSE & -1.2 \\
\hline & P3 protein (Solute carrier family 10 member 3 ) & P3_HUMAN & -1.2 \\
\hline & Ras-related protein Rab-24 & RAB24_HUMAN & -1.2 \\
\hline & Protein TMED8 & TMED8_HUMAN & -1.3 \\
\hline & & & \\
\hline & Doublecortin domain-containing protein 2 & DCDC2_HUMAN & +1.4 \\
\hline & Probable ATP-dependent RNA helicase DDX49 (EC 3.6.1.-) & DDX49_HUMAN & +1.2 \\
\hline & $\begin{array}{l}\text { Hemagglutinin/amebocyte aggregation factor precursor (18K- } \\
\text { LAF) }\end{array}$ & HAAF_LIMPO & +1.2 \\
\hline & Ig kappa chain V region K29-213 & KV15_RABIT & +1.2 \\
\hline & Ig lambda-1 chain $\mathrm{C}$ region & LAC1_MOUSE & +1.2 \\
\hline & Protein phosphatase 1 regulatory subunit $12 \mathrm{~A}$ & MYPT1_HUMAN & +1.3 \\
\hline & Serum amyloid P-component precursor (SAP) & SAMP_CAVPO & +1.2 \\
\hline & Protein yippee-like 5 & YPEL5_PONPY & +1.3 \\
\hline & Dystrophin & DMD_CHICK & -1.3 \\
\hline & Late embryogenesis abundant protein 1 (Aavlea1) & LEA1_APHAV & -1.3 \\
\hline & $\begin{array}{l}\text { LIM domain-containing protein } 2 \\
\text { Leucine-rich repeat-containing protein } 1 \text { (LAP and no PDZ } \\
\text { protein) }\end{array}$ & $\begin{array}{l}\text { LIMD2_BOVIN } \\
\text { LRRC1_HUMAN }\end{array}$ & $\begin{array}{l}-1.2 \\
-1.2\end{array}$ \\
\hline & RNA-binding protein 12 (RNA-binding motif protein 12) & RBM12_MACMU & -1.3 \\
\hline & Receptor expression-enhancing protein 3 & REEP3_BRARE & -1.3 \\
\hline & RuvB-like 2 (EC 3.6.1.-) (Reptin) (zReptin) & RUVB2_BRARE & -1.3 \\
\hline & Surfeit locus protein 2 (Surf-2) & SURF2_FUGRU & -1.4 \\
\hline & CSL-type zinc finger-containing protein 3 & ZCSL3_HUMAN & -1.3 \\
\hline & HEAT repeat-containing protein 2 & HEAT2_HUMAN & -1.3 \\
\hline
\end{tabular}

Table 5. Detailed group of hepatic transcripts involved in metabolism exhibiting lower (italic letters) or higher (normal letters) abundance in fish fed the $100 \%$ plant diet compared to fish fed fish oil and meal, $8 \mathrm{~h}$ after the last meal ( $\mathrm{n}=6$ individuals per group). These data were extracted from statistical analysis of microarrays (FDR $=5.45 \%$ ) for detection of differentially expressed genes and then from gene ontology analysis (GoMiner) for clustering genes by function. + and - regulation means that the target gene is expressed at a lower or higher level, respectively.

\section{Biological \\ Process}

\section{Protein Metabolism}

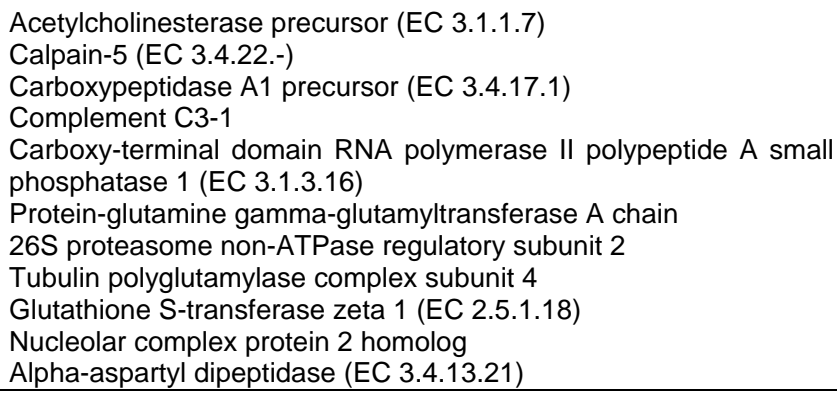

\section{best_swissprot hit_accession number


Polysialoglycoprotein precursor (PSGP)

$60 S$ ribosomal protein L36a (60S ribosomal protein L44)

28 ribosomal protein S26, mitochondrial precursor (MRP-S26)

SPRY domain-containing SOCS box protein 1 (SSB-1)

Threonyl-tRNA synthetase, cytoplasmic (EC 6.1.1.3)

Tubulin-specific chaperone cofactor E-like protein

Transmembrane BAX inhibitor motif-containing protein 4

Amyloid protein-binding protein 1 (APP-BP1)

Acrosin precursor (EC 3.4.21.10)

Anaphase-promoting complex subunit 2 (APC2)

Actin-related protein 6 (hArp6)

Ankyrin repeat and SOCS box protein 13 (ASB-13)

Cell division cycle protein 23 homolog

Eukaryotic translation initiation factor 2-alpha kinase 4 (EC

2.7.11.1)

Translation initiation factor elF-2B subunit delta

HECT domain and RCC1-like domain-containing protein 2

Hepatocyte growth factor-like protein [Precursor]

MAP/microtubule affinity-regulating kinase 3 (EC 2.7.11.1)

Transmembrane protease, serine 6 (EC 3.4.21.-)

Ubiquitin fusion degradation protein 2

Acrosin precursor (EC 3.4.21.10)

Lipid metabolism

Anaphase-promoting complex subunit 2 (APC2)

\begin{tabular}{ll}
\hline PSGP_ONCMY & +1.3 \\
RL36__RAT & +1.2 \\
RT26_RAT & +1.3 \\
SSB1_HUMAN & +1.3 \\
SYTC_MOUSE & +1.3 \\
TBCEL_MOUSE & +1.2 \\
TMBI4_MOUSE & +1.2 \\
ULA1_BRARE & +1.2 \\
& \\
ACRO_HUMAN & -1.4 \\
ANC2_HUMAN & -1.3 \\
ARP6_HUMAN & -1.3 \\
ASB13_HUMAN & -1.4 \\
CDC23_HUMAN & -1.2 \\
& -1.2 \\
E2AK4_MOUSE & \\
EI2BD_RAT & -1.2 \\
HERC2_MOUSE & -1.3 \\
HGFL_HUMAN & -1.3 \\
MARK3_HUMAN & -1.2 \\
TMPS6_MOUSE & -1.2 \\
UBE4B_HUMAN & -1.2 \\
ACRO_HUMAN & -1.3 \\
ANC2_HUMAN & -1.3 \\
&
\end{tabular}

Acyl-coenzyme A thioesterase 1 (EC 3.1.2.2)

ACOT1_RAT

$+1.3$

3,2-trans-enoyl-CoA isomerase, mitochondrial precursor (EC 5.3.3.8)

24-dehydrocholesterol reductase precursor (EC 1.3.1.-)

D3D2_MOUSE

DHC24_HUMAN

3-beta-hydroxysteroid-delta(8), delta(7)-isomerase (EC 5.3.3.5)

Trifunctional enzyme subunit alpha, mitochondrial precursor (TPalpha)

EBP_HUMAN

$+1.4$

$+1.3$

$+1.2$

C-4 methylsterol oxidase (EC 1.14.13.72)

ECHA_HUMAN

ERG25_BRARE

$+1.4$

Delta-5/delta-6 fatty acid desaturase (EC 1.14.19.-)

FADS_BRARE

$+1.5$

Glycerol kinase (EC 2.7.1.30)

GLPK_PYRAB

$+1.3$

Cytosolic phospholipase A2 (cPLA2)

PA24A_HUMAN

Putative phosphoethanolamine $\mathrm{N}$-methyltransferase 3 (EC 2.1.1.103)

PEAM3_ARATH

PCTP-like protein (PCTP-L) (StAR-related lipid transfer protein 10)

PCTL_MOUSE

Arylacetamide deacetylase (EC 3.1.1.-) (AADAC)

AAAD_HUMAN

ATP-citrate synthase (EC 2.3.3.8)

Diacylglycerol kinase beta (EC 2.7.1.107)

ACLY_MOUSE

Dehydrogenase/reductase SDR family member 8 precursor (EC 1.1.1.-)

$D G K B \_R A T$

DHRS8_HUMAN

Acyl-CoA:lysophosphatidylglycerol acyltransferase 1 (EC 2.3.1.-)

LGAT1_HUMAN

\section{Glucose metabolism}

\section{Nucleic acid

Glucose-1-phosphate cytidylyltransferase (EC 2.7.7.33)

Rhamnose-binding lectin precursor (SAL) (RBL)

RFBF_SALTY

Carbohydrate sulfotransferase 1 (EC 2.8.2.21)

SAL_SILAS

Glycoprotein 6-alpha-L-fucosyltransferase

CHST1_BRARE

Hexokinase-2 (EC 2.7.1.1)

Phosphoglucomutase-2 (EC 5.4.2.2)

Phosphoenolpyruvate carboxykinase [GTP], mitochondrial precursor (EC 4.1.1.32)

FUT8 PANTR

HXK2_HUMAN

PGM2_HUMAN 


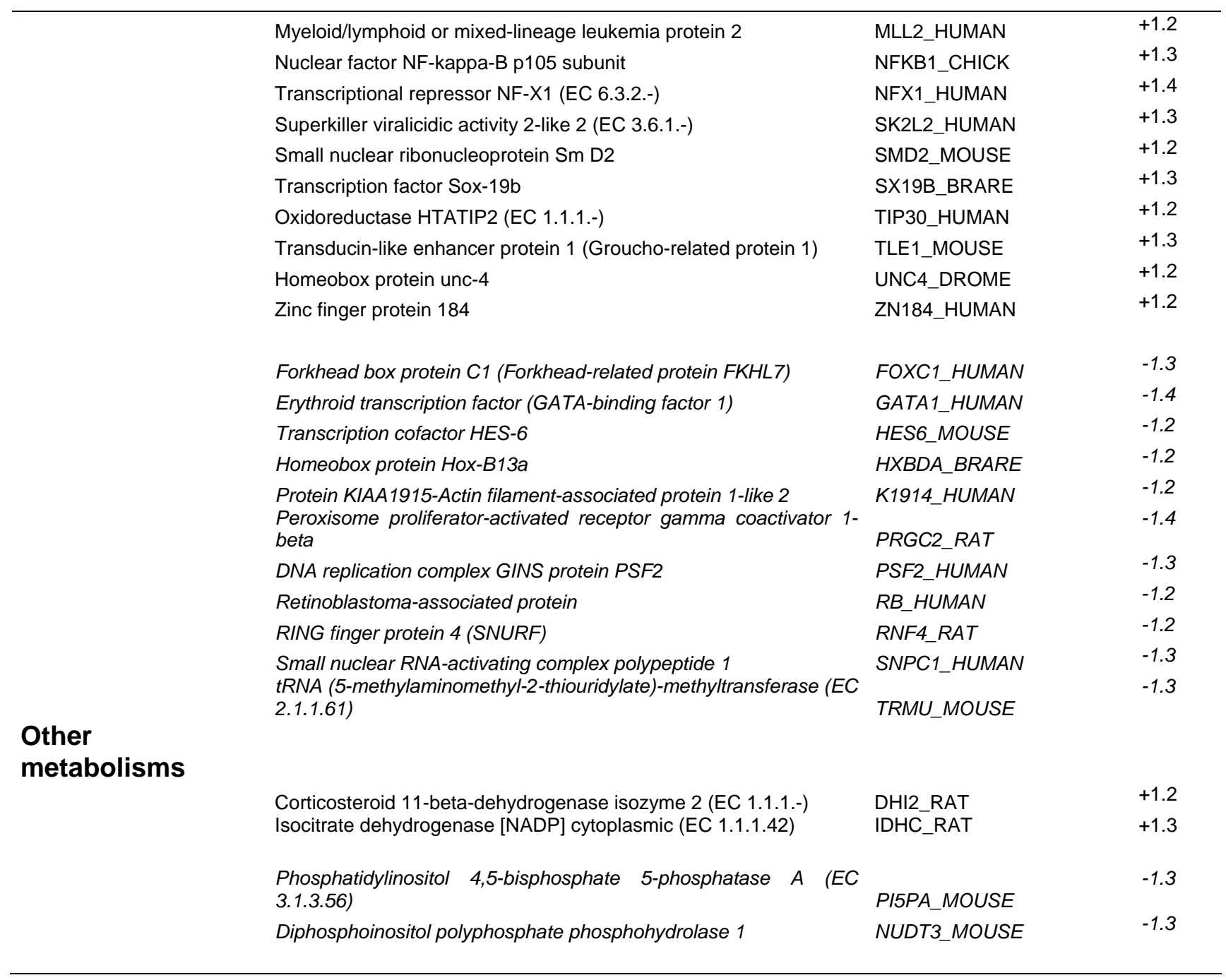

